\title{
Research Article \\ Substantial Depletion of Vicine, Levodopa, and Tyramine in a Fava Bean Protein-Based Nutritional Product
}

\author{
Paul W. Johns $\mathbb{D}$ and Steven R. Hertzler $\mathbb{D}$ \\ Abbott Laboratories, Abbott Nutrition Division, 3300 Stelzer Road, Columbus, OH, USA 43219 \\ Correspondence should be addressed to Paul W. Johns; pjohns@columbus.rr.com
}

Received 5 November 2020; Revised 1 January 2021; Accepted 16 January 2021; Published 30 January 2021

Academic Editor: Chaowalit Monton

Copyright (c) 2021 Paul W. Johns and Steven R. Hertzler. This is an open access article distributed under the Creative Commons Attribution License, which permits unrestricted use, distribution, and reproduction in any medium, provided the original work is properly cited.

\begin{abstract}
A commercial fava bean protein isolate and a liquid nutritional product formulated with it were tested by validated HPLC methods for the favism-associated pyrimidine glycoside vicine, the dopamine precursor levodopa, and the biogenic amine tyramine. The vicine, levodopa, and tyramine concentrations in the protein isolate-306, 13.3, and $<0.5 \mathrm{mg} / \mathrm{kg}$, respectively-when expressed on a protein basis-34, 1.5 , and $<0.06 \mathrm{mg} / 100 \mathrm{~g}$ protein, respectively-were at least $96 \%$ lower than the vicine, levodopa, and tyramine (protein-based) concentrations reported for fava beans $(\geq 900, \sim 200$, and $\sim 4 \mathrm{mg} / 100 \mathrm{~g}$ protein, respectively). This was also true for the vicine $(13 \mathrm{mg} / \mathrm{kg}$ or $22 \mathrm{mg} / 100 \mathrm{~g}$ protein), levodopa $(\leq 0.17 \mathrm{mg} / \mathrm{kg}$ or $\leq 0.3 \mathrm{mg} / 100 \mathrm{~g}$ protein), and tyramine $(0.08 \mathrm{mg} / \mathrm{kg}$ or $0.14 \mathrm{mg} / 100 \mathrm{~g}$ protein) concentrations in the nutritional product. On the basis of these data, one serving (11 fl. oz.) of the nutritional product would deliver approximately $5 \mathrm{mg}$ of vicine, $<1 \mathrm{mg}$ of levodopa, and $<0.1 \mathrm{mg}$ of tyramine.
\end{abstract}

\section{Introduction}

The fava bean (Vicia faba) has been identified as a "highprotein crop" suitable for large-scale cultivation as a sustainable plant source of dietary protein [1]. Fava beans contain $24-32 \%(w / w)$ protein, and the fava bean protein (like the protein from soy and other legumes) does not exhibit the human dietary lysine deficiency associated with cereal proteins (Cardador-Martinez et al. 2014, [2]). By virtue of these and additional attributes-including nitrogen fixation capacity and soybean substitution potential - fava beans (with a global production of 4.1 million tons in 2014) are regarded as one of the more globally important legume crops, and research directed at increasing yield, protein, and stress resistance, as well as decreasing antinutritional factors, is underway [2-5].

In addition to the antinutritional factors common to legumes (phytic acid, saponins, polyphenols, and protease inhibitors), fava beans typically contain three additional components of physiological significance: (a) uniquely high levels of vicine (VC) and related pyrimidines (aka alkaloids), (b) the nonproteinogenic amino acid levodopa (LD), aka, Ldopa and L-3,4-dihydroxyphenylalanine, and (c) the tyrosine decarboxylation product and biogenic amine tyramine (TY) [6]. The two pyrimidine glycosides - VC and convicine-and their respective aglycones-divicine and isouramil-when ingested in millimole quantities may cause the acute hemolytic anemia condition known as "favism" [5]. The dopamine precursor LD may induce both powerful therapeutic ("the most efficacious drug" and the "gold standard" for treating Parkinson's disease) and also adverse (gastrointestinal disturbances, hallucinations, dyskinesias, and even favism) effects [7-10]. TY (which, along with histamine, "is well established as the most toxicologically active biogenic amines, due to their relatively low threshold toxic level-'as low as $6 \mathrm{mg}$ of TY in a 4-hour period'-in addition to the severity of the symptoms they may cause") has been associated with "peripheral vasoconstriction, increased cardiac output, increased respiration, elevated blood glucose, and release of norepinephrine" [11-15].

Favism can be prevented by decreasing VC consumption, and researchers have identified several means to effect this decrease, including fava bean germination, fermentation, glucosidase treatment, cooking, roasting, autoclaving, protein precipitation, and selective cultivar breeding $([16,17]$, 
Cardador-Martinez et al. 2014, [3, 5, 18-21]). The isolation of fava bean protein by isoelectric precipitation has been shown to be especially effective in lowering the VC presence, with reductions $>99 \%$ reported $[17,21]$. Similar reductions of LD and TY may be expected to accompany the fava bean protein isolation process, since both LD and TY are (like VC) relatively small, water-soluble molecules, and therefore subject to separation from the major fava bean proteins $(\mathrm{MW} \geq 20,000 \mathrm{Da})[21]$.

In view of these considerations, the objective of the present study was to determine the concentrations of these biologically significant fava bean components-VC, LD, and TY - in a commercial fava bean protein isolate (FBPI) and in a nutritional product (NP) formulated with the FBPI. The determinations were performed by reversed phase HPLC methods that are described below, along with the validation experimentation completed for each method. The experimental FBPI and NP VC, LD, and TY concentrations were then compared to published fava bean concentrations, as a means of verifying the safety of the FBPI-based NP.

\section{Materials and Methods}

2.1. Materials. Tyramine hydrochloride and vicine reference materials were obtained from Sigma-Aldrich (St. Louis, MO, USA). The levodopa reference standard was obtained from the United States Pharmacopeia (Rockville, MD, USA). Potassium phosphate monobasic was also obtained from Sigma-Aldrich (St. Louis, MO, USA). $6 \mathrm{M}$ hydrochloric acid ( $\mathrm{HCl})$, double distilled, catalog \#504, was obtained from GFS Chemicals (Columbus, OH, USA). HPLC grade acetonitrile $(\mathrm{ACN})$ and methanol were obtained from Honeywell Burdick \& Jackson (Muskegon, MI, USA). FBPIs were obtained from commercial protein suppliers. The NPs (obtained from Abbott Nutrition, a division of Abbott Laboratories (Chicago, IL, USA)) comprised fava bean protein-based, shelf-stable, oil-in-water emulsions, containing approximately $4 \%(w / w)$ carbohydrate, $2 \%(w / w)$ fat, and $6 \%(w / w)$ protein, and containing both water- and oilsoluble vitamins ( $\mathrm{A}, \mathrm{B}, \mathrm{C}, \mathrm{D}, \mathrm{E}$, and $\mathrm{K})$, minerals, other micronutrients, buffers, and flavoring agents (vanilla and cocoa powder). The NP carbohydrate included sucrose and fiber, the fat included high oleic safflower oil, and the protein included fava bean and pea.

2.2. HPLC Instrumentation and Columns. Direct HPLC determinations of VC, LD, and TY were performed on an Agilent Model 1260 HPLC system (Agilent Technologies, Wilmington, DE, USA), using the equipment and parameters specified in Table 1.

2.3. Analyte Extraction Procedures. Since all three analytes (VC, LD, and TY) are relatively small molecules $(\mathrm{MW} \leq 304 \mathrm{Da})$ with appreciable water solubility $(\geq 5 \mathrm{~g} / \mathrm{L}$ at $20^{\circ} \mathrm{C}$; Yalkowsky and Dannenfelser, 1992), the procedures for VC, LD, and TY extraction from FBPIs and NPs were adapted from published procedures developed previously for the extraction of similar relatively small, water-soluble analytes, including methionine, arginine, glutamine, $\beta$-alanine, $\beta$-hydroxy- $\beta$-methylbutyrate, and 5 -methyltetrahydrofolic acid [22-25].

2.4. Preparation of VC Reference Standard Solutions. A VC reference standard stock solution was prepared by dissolving $1.10-1.50 \mathrm{mg}$ of VC (accurately weighed) in $10 \mathrm{~mL}$ of Milli-Q Plus water. A reference standard intermediate solution was prepared by diluting $8.00 \mathrm{~mL}$ of the stock solution to $50 \mathrm{~mL}$ with Milli-Q Plus water. Reference standard solutions A-E were prepared by pipetting $1.00,2.00,3.00,4.00$, and $5.00 \mathrm{~mL}$ of reference standard intermediate solution into individual $25 \mathrm{~mL}$ volumetric flasks and diluting each to volume with HPLC Mobile Phase A. The five vials obtained by this procedure (reference standard solutions A-E) are used to calibrate each HPLC determination of VC, convicine, divicine, and isouramil. The $\mathrm{VC}$ concentrations in the standard solutions range from $0.70-0.96 \mathrm{mg} / \mathrm{L}$ (A) to $3.5-4.8 \mathrm{mg} / \mathrm{L}$ (E), or $2.3-3.2 \mu \mathrm{M}$ (A) to $12-16 \mu \mathrm{M}$.

2.5. Preparation of FBPIs and NPs for the Determination of $V C$. An aqueous suspension of the FBPI was prepared by (a) transferring $0.80-0.85 \mathrm{~g}$ of FBPI (accurately weighed) into a $100 \mathrm{~mL}$ glass bottle, (b) adding $100 \mathrm{~mL}$ of Milli-Q Plus water and a stir bar to the bottle, (c) capping the bottle, and (d) stirring the mixture vigorously for thirty minutes at room temperature $\left(21^{\circ} \mathrm{C}\right)$. An aliquot of the FBPI suspension was centrifuged at $15,000 \times g$ for five minutes, and the supernatant was syringe filtered through a $0.45 \mu \mathrm{m}$ PTFE membrane into an HPLC autosampler vial. The vial was sealed and tested for $\mathrm{VC}$, convicine, divicine, and isouramil by the HPLC system outlined in Table 1, after calibration with reference standard solutions A-E. It should be noted that in the absence of a reference standard for convicine, divicine, and isouramil, their concentrations were estimated from the VC calibration curve. In each case, the UV molar response (peak area at $276 \mathrm{~nm}$ ) was assumed to approximate the VC UV molar response, so that mass-based concentrations $(\mathrm{mg} / \mathrm{kg})$ were calculated using the corresponding MW ratio factor: the convicine mass conversion factor $=$ $305.2 / 304.3=1.003$, the divicine mass conversion factor $=$ $142.1 / 304.3=0.467$, and the isouramil mass conversion factor $=143.1 / 304.3=0.470$.

The NP was prepared by (a) pipetting 10-11 g (accurately weighed) of NP into a $100 \mathrm{~mL}$ volumetric flask, (b) diluting to volume with HPLC Mobile Phase A, (c) carefully adding a stir bar and a stopper, and (d) stirring vigorously for thirty minutes at room temperature $\left(21^{\circ} \mathrm{C}\right)$. An aliquot of the suspension was centrifuged at $15,000 \times g$ for five minutes, and the supernatant was syringe filtered through a $0.45 \mu \mathrm{m}$ PTFE membrane into an HPLC autosampler vial. The prepared sample was tested for VC by the HPLC system outlined in Table 1, after calibration with reference standard solutions A-E.

2.6. Preparation of LD Reference Standard Solutions. A LD reference standard stock solution was prepared by dissolving 10-11 mg of USP LD reference standard (accurately weighed) in $25 \mathrm{~mL}$ of Milli-Q Plus water. Low, middle, and high standard solutions were prepared by pipetting $0.0200,0.100$, 
TABLE 1: HPLC instrumentation and parameters.

\begin{tabular}{|c|c|c|c|c|}
\hline Analyte(s) & $\begin{array}{c}\text { Vicine, convicine, } \\
\text { divicine, and isouramil in } \\
\text { FBPI }\end{array}$ & Vicine in NP & Levodopa & Tyramine \\
\hline LC system & \multicolumn{4}{|c|}{ Agilent Model 1260 (Agilent Technologies, Wilmington, DE, USA) } \\
\hline Detector & \multicolumn{2}{|c|}{ Agilent G4212B diode array } & \multicolumn{2}{|c|}{ Agilent G1321A fluorescence } \\
\hline $\begin{array}{l}\text { Detection } \\
\text { wavelengths }\end{array}$ & $\begin{array}{c}276 \mathrm{~nm}, 214 \mathrm{~nm}, 273 \mathrm{~nm}, \\
278 \mathrm{~nm}, 283 \mathrm{~nm}\end{array}$ & $276 \mathrm{~nm}, 214 \mathrm{~nm}$ & $\begin{array}{l}\mathrm{Ex}=280 \mathrm{~nm} \\
\mathrm{Em}=310 \mathrm{~nm}\end{array}$ & $\begin{array}{l}\mathrm{Ex}=275 \mathrm{~nm} \\
\mathrm{Em}=303 \mathrm{~nm}\end{array}$ \\
\hline LC column & YMC-Pack ODS-AQ ${ }^{\mathrm{a}}$ & Zorbax Eclipse Plus C18 ${ }^{\mathrm{b}}$ & Zorbax Eclipse Plus C18 ${ }^{\mathrm{b}}$ & YMC-Pack ODS-AQ ${ }^{\mathrm{a}}$ \\
\hline Temperature & $25^{\circ} \mathrm{C}$ & $15^{\circ} \mathrm{C}$ & $20^{\circ} \mathrm{C}$ & $15^{\circ} \mathrm{C}$ \\
\hline $\begin{array}{l}\text { Mobile } \\
\text { phase A }\end{array}$ & \multicolumn{2}{|c|}{$0.05 \mathrm{M} \mathrm{KH}_{2} \mathrm{PO}_{4}, \mathrm{pH} 2.9$} & $\begin{array}{c}1000 / 25(v / v) 0.05 \mathrm{M} \\
\mathrm{KH}_{2} \mathrm{PO}_{4}, \mathrm{pH} 2.9 / \mathrm{ACN}\end{array}$ & $0.02 \mathrm{M} \mathrm{KH}_{2} \mathrm{PO}_{4}, \mathrm{pH} 2.9$ \\
\hline $\begin{array}{l}\text { Mobile } \\
\text { phase B }\end{array}$ & \multicolumn{4}{|c|}{$200 / 800(v / v) \mathrm{H}_{2} \mathrm{O} / \mathrm{ACN}$} \\
\hline Flow rate & $0.5 \mathrm{~mL} / \mathrm{min}$ & $0.4 \mathrm{~mL} / \mathrm{min}$ & $0.4 \mathrm{~mL} / \mathrm{min}$ & $0.5 \mathrm{~mL} / \mathrm{min}$ \\
\hline Injection & $10 \mu \mathrm{L}$ & $10 \mu \mathrm{L}$ & $5 \mu \mathrm{L}$ & $10 \mu \mathrm{L}$ \\
\hline $\begin{array}{l}\text { Elution } \\
\text { program }\end{array}$ & $\begin{array}{l}0 \% \text { B } 0-20 \text { min, } 100 \% \text { B } \\
20-25 \min , 0 \% \text { B } 25- \\
45 \text { min (end) }\end{array}$ & $\begin{array}{l}\text { 0\% B 0-25 min, } 100 \% \text { B } \\
25-30 \text { min, } 0 \% \text { B } 30- \\
45 \text { min (end) }\end{array}$ & $\begin{array}{c}0 \% \text { B } 0-25 \mathrm{~min}, 100 \% \text { B } 25- \\
30 \mathrm{~min}, 0 \% \text { B } 30-50 \mathrm{~min} \\
\text { (end) }\end{array}$ & $\begin{array}{c}0 \% \text { B } 0-5 \mathrm{~min}, 0-10 \% \text { B } 5-25 \mathrm{~min} \\
\text { (linear), } 100 \% \text { B } 25-30 \mathrm{~min}, 0 \% \text { B 30- } \\
45 \text { min (end) }\end{array}$ \\
\hline
\end{tabular}

${ }^{\mathrm{a}} 4.6 \times 250 \mathrm{~mm}, 5 \mu \mathrm{m}, 120 \AA \AA$; Waters Corporation, Milford, MA, USA. ${ }^{\mathrm{b}} 4.6 \times 250 \mathrm{~mm}, 5 \mu \mathrm{m}$; Agilent Technologies, Wilmington, DE, USA.

and $0.200 \mathrm{~mL}$ of reference standard stock solution into individual $10 \mathrm{~mL}$ volumetric flasks and diluting each to volume with HPLC Mobile Phase A. The three vials obtained by this procedure were used to calibrate each HPLC determination of LD. The LD concentrations in the standard solutions ranged from $0.80-0.88 \mathrm{mg} / \mathrm{L}$ (low standard solution) to 8.0 $8.8 \mathrm{mg} / \mathrm{L}$ (high standard solution), or from $4.1-4.5 \mu \mathrm{M}$ to 41-45 $\mu \mathrm{M}$, respectively.

2.7. Preparation of FBPIs and NPs for the Determination of $L D$. The FBPI was prepared for LD determination by (a) weighing $0.9-1.1 \mathrm{~g}$ of FBPI into a tared $20 \mathrm{~mL}$ glass vial, (b) adding $20.0 \mathrm{~mL}$ of Mobile Phase A and a stir bar to the vial, (c) capping the bottle, and (d) stirring the mixture vigorously for thirty minutes at room temperature $\left(21^{\circ} \mathrm{C}\right)$. The FBPI suspension was filtered through Whatman No. 41 paper, and the filtrate was syringe filtered through a $0.45 \mu \mathrm{m}$ PTFE membrane into an HPLC autosampler vial. The vial was sealed and tested for LD by the HPLC system outlined in Table 1, after calibration with the low, middle, and high standard solutions.

The NP was prepared by (a) pipetting $20.0 \mathrm{~mL}$ (accurately weighed) of NP into a $50 \mathrm{~mL}$ Erlenmeyer flask, (b) adding $20.0 \mathrm{~mL}$ of HPLC Mobile Phase A, (c) carefully adding a stir bar and a stopper, and (d) stirring vigorously for sixty minutes at room temperature $\left(21^{\circ} \mathrm{C}\right)$. An aliquot of the suspension was centrifuged at $30,000 \times g$ and at $20^{\circ} \mathrm{C}$ for 1 hour, the supernatant was ultrafiltered with a Pall Microsep ${ }^{\mathrm{TM}}$ Advance $30 \mathrm{~K}$ Centrifugal Device, and the ultrafiltrate was syringe filtered through a $0.2 \mu \mathrm{m}$ PTFE membrane into an HPLC autosampler vial. The prepared sample was tested for LD by the HPLC system outlined in Table 1, after calibration with the low, middle, and high standard solutions.

2.8. Preparation of TY Standard Solutions. A TY stock standard solution was prepared by dissolving $28-30 \mathrm{mg}$ of TY
$\mathrm{HCl}$ reference material (accurately weighed) in $250 \mathrm{~mL}$ of Milli-Q Plus water. Low, middle, and high standard solutions were prepared by pipetting $2.00 \mathrm{~mL}$ of TY stock standard solution into $2000 \mathrm{~mL}, 1000 \mathrm{~mL}$, and $500 \mathrm{~mL}$ volumetric flasks, respectively, and diluting each to volume with MilliQ Plus water. The low, middle, and high standard solutions obtained by this procedure were used to calibrate each HPLC determination of TY. The TY concentrations in the standard solutions ranged from $0.089-0.095 \mathrm{mg} / \mathrm{L}$ (low standard solution) to $0.35-0.38 \mathrm{mg} / \mathrm{L}$ (high standard solution), or from $0.65-0.69 \mu \mathrm{M}$ to $2.6-2.8 \mu \mathrm{M}$, respectively.

2.9. Preparation of FBPIs and NPs for the Determination of TY. The FBPI was prepared for TY determination by (a) weighing $0.9-1.1 \mathrm{~g}$ of FBPI into a tared $100 \mathrm{~mL}$ volumetric flask, (b) diluting to volume with Mobile Phase A (with swirling to thoroughly disperse the FBPI), (c) adding a stir bar and a stopper to the flask, and (d) stirring the mixture vigorously for fifteen minutes at room temperature $\left(21^{\circ} \mathrm{C}\right)$. The FBPI suspension was syringe filtered through a $0.45 \mu \mathrm{m}$ PTFE membrane into an HPLC autosampler vial. The vial was sealed and tested for TY by the HPLC system outlined in Table 1, after calibration with the low, middle, and high standard solutions.

The NP was prepared by (a) pipetting $10.0 \mathrm{~mL}$ (accurately weighed) of NP into a $100 \mathrm{~mL}$ volumetric flask, (b) diluting to volume with HPLC Mobile Phase A, (c) carefully adding a stir bar and a stopper, and (d) stirring vigorously for fifteen minutes at room temperature $\left(21^{\circ} \mathrm{C}\right)$. An aliquot of the suspension was centrifuged at $30,000 \times g$ and at $20^{\circ} \mathrm{C}$ for $30 \mathrm{~min}$, and the supernatant was syringe filtered through a $0.45 \mu \mathrm{m}$ PTFE membrane into an HPLC autosampler vial. The prepared sample was tested for TY by the HPLC system outlined in Table 1, after calibration with the low, middle, and high standard solutions. 
2.10. Method Validation Experimentation. Experiments were performed to assess method linearity, precision, accuracy, and selectivity. The purity of the VC reference standard was evaluated by comparing its UV molar extinction coefficient to a published value. Linear response was assessed as standard curve coefficient of determination, intermediate precision was assessed as within-day and/or day-to-day RSD (relative standard deviation, which was calculated as $[\mathrm{SD} \times$ $100 \%$ ]/average, where SD is the standard deviation [associated with the analyte concentration average], and average is the average of the experimentally determined analyte concentrations, e.g., the RSD for vicine concentrations of 282 , 316 , and $319 \mathrm{mg} / \mathrm{kg}$ would be calculated as $[21 \times 100 \%] / 306$ $=6.9 \%$, where $\mathrm{SD}=21 \mathrm{mg} / \mathrm{kg}$ and where the average vicine concentration is $306 \mathrm{mg} / \mathrm{kg}$ ), accuracy was assessed by known addition recovery experimentation, and analyte selectivity was demonstrated as baseline chromatographic resolution of the analyte from a compound of similar structure (e.g., VC vs. convicine, and TY vs. free tyrosine) and/or by the absence of chromatographic interference in standard and sample reagent blanks. For each analyte (VC, LD, and TY), the limit of detection (LOD) and the limit of quantitation (LOQ) were estimated by "the most widespread approach used in HPLC methods": by analyte signal comparison to a manually measured standard blank noise basis, where the LOD corresponds to the analyte concentration exhibiting a signal-to-noise $(\mathrm{S} / \mathrm{N})$ ratio $=3$, and where the LOQ corresponds to the analyte concentration exhibiting a $\mathrm{S} / \mathrm{N}=10[26]$.

\section{Results and Discussion}

3.1. VC Method Validation. The UV molar extinction coefficient $(13,250 \mathrm{~L} / \mathrm{molecm}, 275 \mathrm{~nm}, \mathrm{pH} 6.8)$ of the SigmaAldrich VC reference standard was $100.4 \%$ of a published value $(13,200 \mathrm{~L} / \mathrm{molecm}, 275 \mathrm{~nm}, \mathrm{pH} 6.8$; [27]) and was accordingly regarded as $100 \%$ pure. Standard curve linearity was evaluated as the coefficient of determination $\left(R^{2}\right)$ for five VC standard curves (VC concentration range $\sim 0.8$ to $\sim 4 \mathrm{mg} / \mathrm{L}) . R^{2}$ exceeded 0.9990 for each of the five plots, and the $y$-intercept averaged $0.9 \pm 0.8 \%(n=5)$ of the standard solution C (middle standard) peak area.

Precision, as within-day RSD values for a commercial lot of FBPI, was $0.3 \%(n=3), 0.5 \%(n=3)$, and $0.4 \%$ $(n=3)$ for days 1,2 , and 3 , respectively. The average $\mathrm{VC}$ concentration for the series of determinations was $290 \pm 4$ $\mathrm{mg} / \mathrm{kg}$ ( $n=3$ days), so that the day-to-day RSD was $1.4 \%$. When three different lots of FBPI obtained from the same supplier were tested, an average VC concentration of $306 \pm$ $20 \mathrm{mg} / \mathrm{kg}$ was obtained, so that the lot-to-lot RSD was $6.7 \%$ $(n=3$ lots, Table 2$)$.

Two assessments of method accuracy were performed. In the first experiment, a commercial FBPI was prepared for vicine determination by five different procedures, including (a) the sample preparation described above (control), (b) the control procedure with stirring time extended from $30 \mathrm{~min}$ to $60 \mathrm{~min}$, (c) the control procedure with temperature increased from $21^{\circ} \mathrm{C}$ to $75^{\circ} \mathrm{C}$, (d) the control procedure using methanol/water $(50 / 50, v / v)$ as the extraction medium, and
TABLE 2: Pyrimidine concentrations, as $\mathrm{mg} / \mathrm{kg}$, in a commercial fava bean protein isolate.

\begin{tabular}{lcccc}
\hline Alkaloid & Lot 1 & Lot 2 & Lot 3 & Average (RSD; $n=3$ lots) \\
\hline Vicine & 282 & 316 & 319 & $306 \pm 21(6.7 \%)$ \\
Convicine* $^{*}$ & 66 & 91 & 86 & $81 \pm 13(16 \%)$ \\
Divicine* $^{*}$ & 4 & 4 & 4 & $4 \pm 0(0 \%)$ \\
Isouramil $^{*}$ & 5 & 10 & 10 & $8 \pm 3(40 \%)$ \\
Sum & 357 & 421 & 419 & $399 \pm 36(9.0 \%)$ \\
\hline
\end{tabular}

${ }^{*}$ The concentrations of convicine, divicine, and isouramil were estimated using the vicine standard curve (with adjustment for MW differences).

(e) the control procedure using HPLC Mobile Phase A as the extraction medium. Each preparation was tested for vicine concentration, which ranged from 290 to $293 \mathrm{mg}$ per $\mathrm{kg}$ FBPI, with an average of $291 \pm 1 \mathrm{mg} / \mathrm{kg}(n=5)$. There was no significant difference among the five preparations, indicating that an increase in stirring time (b), an increase in extraction temperature (c), an increase in extraction medium hydrophobicity (d), and a decrease in extraction medium $\mathrm{pH}(\mathrm{e})$ failed to result in a vicine concentration increase, thereby verifying that vicine was quantitatively extracted by the control procedure (a). In the second experiment, each of the two NPs formulated with an FBPI was tested, without and with VC spiking at $25 \mathrm{mg} / \mathrm{kg}$, for VC. The VC concentrations determined in the unspiked samples were 12.5 and $12.8 \mathrm{mg} / \mathrm{kg}$, and the recoveries of the spiked VC were $100 \%$ and $99.9 \%$, respectively. Both experimental assessments support the capacity of the method to accurately determine the vicine concentration in FBPIs and in NPs.

Baseline separation of the pyrimidine glycosides-VC (elution time $=19.3 \mathrm{~min}, \mathrm{UV} \max =276 \mathrm{~nm}$ ) and convicine (elution time $=20.3 \mathrm{~min}, \mathrm{UV} \max =273 \mathrm{~nm}$ ) —and baseline separation of their respective aglycones-divicine (elution time $=7.7 \mathrm{~min}, \mathrm{UV} \max =283 \mathrm{~nm}$ ) and isouramil (elution time $=10.8 \mathrm{~min}$, UV $\max =278 \mathrm{~nm}$ ) - were demonstrated. In the absence of reference materials, the convicine, divicine, and isouramil peaks were identified by their diode array UV spectra. Absence of a VC response in standard and sample blanks was also verified.

The VC LOD and LOQ for a FBPI were experimentally determined to be $3 \mathrm{mg} / \mathrm{kg}$ or $10 \mu$ moles $/ \mathrm{kg}$ and $10 \mathrm{mg} / \mathrm{kg}$ or $30 \mu$ moles $/ \mathrm{kg}$, respectively. The VC LOD and LOQ for the $\mathrm{NP}$ were $1 \mathrm{mg} / \mathrm{kg}$ or $3 \mu \mathrm{moles} / \mathrm{kg}$ and $3 \mathrm{mg} / \mathrm{kg}$ or $10 \mu \mathrm{mo}-$ les $/ \mathrm{kg}$, respectively. Both LOQs were well below the VC concentrations expected to reside in the FBPIs $(\sim 300 \mathrm{mg} / \mathrm{kg})$ and in the NPs $(\sim 12 \mathrm{mg} / \mathrm{kg})$ of interest.

3.2. LD Method Validation. The linearity of the LD response was verified by the strong positive correlation between LD peak area and concentration $\left(R^{2}=1.0000\right)$ over the standard curve concentration range ( 0.8 to $8.0 \mathrm{mg} / \mathrm{L})$. Method precision was assessed as within-day RSD (1.5\%) for the triplicate determination of LD in a commercial lot of FBPI (LD average $=13.3 \pm 0.2 \mathrm{mg} / \mathrm{kg} ; n=3$ ). Method selectivity was verified by experimental demonstration of the absence of a detectable chromatographic peak at the LD elution time in (a) a standard blank, (b) a sample blank, and (c) a pea 
protein isolate. The LD method LOQs were $0.5 \mathrm{mg} / \mathrm{kg}$ for protein ingredients and $0.05 \mathrm{mg} / \mathrm{kg}$ for NPs.

3.3. TY Method Validation. The linearity of the TY response was verified by the strong positive correlation between TY peak area and concentration $\left(R^{2}=0.99993\right)$ over the standard curve concentration range ( 0.09 to $0.36 \mathrm{mg} / \mathrm{L}$ ). Method precision was assessed as within-day RSD $(0.4 \%)$ for the triplicate determination of TY in a NP $(0.671 \pm 0.003 \mathrm{mg} / \mathrm{kg} ; n=3)$. Accuracy was assessed by known addition recovery experimentation: the TY spike recovery averaged $98.5 \pm 0.2 \%$, $n=3$, for a NP spiked (in triplicate) at $0.67 \mathrm{mg}$ TY per $\mathrm{kg}$. Method selectivity was verified by experimental demonstration of the baseline resolution of TY and free tyrosine, and by the absence of a detectable chromatographic peak at the TY elution time in a standard blank and in a sample blank. The TY method LOQs were $0.5 \mathrm{mg} / \mathrm{kg}$ for protein ingredients and $0.05 \mathrm{mg} / \mathrm{kg}$ for NPs.

3.4. VC in FBPIs and NPs. The method was applied to three lots of a commercial FBPI (Figure 1). The measured VC concentrations, along with the concentrations estimated for convicine, divicine, and isouramil, are shown in Table 2. The ratio of VC to protein in the FBPI is $\sim 0.034$ to $100, w / w$, which is $96-99 \%$ lower than the ratio of VC to protein in fava beans $(\sim 0.9$ to 100 to $\sim 3.2$ to $100, w / w)$ calculated from published data $([16,28-30]$, CardadorMartinez et al. 2014, [18]). In fact, the reduction approaches the $99+\% \mathrm{VC}$ reduction (fava bean flour to FBPI) achieved by [17]. A VC reduction of this magnitude (96-99\%) is not unexpected in view of the capacity of protein concentration processes to separate the relatively small, hydrophilic alkaloids ( $\mathrm{MW} \leq 305 \mathrm{Da}$ ) from the major fava bean proteins $(\mathrm{MW} \geq 20,000 \mathrm{Da})[21]$. In fact, there are three steps in the FBPI production process that would be expected to remove an appreciable portion of the alkaloids from the protein, namely, the (a) soaking/centrifugation, (b) acid precipitation/centrifugation, and (c) washing/centrifugation steps [31]. In each of the three steps, the aqueous medium would dissolve alkaloids, and these dissolved alkaloids would then be separated from the protein by the subsequent centrifugation. An analogous reduction/removal of soluble sugars and isoflavones (including a preferential reduction of the more soluble isoflavone glucosides vs. the less soluble isoflavone aglycones) has been shown to occur in similar processes used in the production of soy protein isolate from soy protein flour, wherein "washing was the step where most isoflavones were lost" [32]. It is also relevant to note that the soy isoflavones are both larger and less water-soluble than VC, LD, and TY (e.g., the major soy isoflavones daidzin and genistin have MW $=416$ and $432 \mathrm{Da}$, and water solubility $=0.661$ and $1.01 \mathrm{~g} / \mathrm{L}$, respectively $[33,34])$, so that the expectation is that VC, $\mathrm{LD}$, and TY $(\mathrm{MW} \leq 304 \mathrm{Da}$, water solubility $\geq 5 \mathrm{~g} / \mathrm{L}$ ) would be more readily removable than the soy isoflavones. The expectation for extensive VC, $\mathrm{LD}$, and TY reduction during the FBPI production process is further supported by extensive reductions of cresol sulfates and indoxyl sulfate ( $>90 \%$ reduction) and of lactose
( $>99 \%$ reduction) that occur during the production of milk protein concentrates/isolates from milk $[35,36]$.

The method was also applied to two NPs, which were found to contain VC at 12.5 and $12.8 \mathrm{mg} / \mathrm{kg}$ (corresponding to 0.0219 and $0.0224 \mathrm{~g} / 100 \mathrm{~g}$ protein, respectively). These VC concentrations were $77.2 \%$ and $79.0 \%$, respectively, of the VC concentration that was projected from its FBPI ingredient, indicating a processing-induced VCloss of 21-23\%. VC losses in this range are consistent with boiling (average VCloss $=19 \% \pm 12 \%, n$ $=10)$, stewing $\quad(\mathrm{VC}+$ convicine loss $=21.6 \%), \quad$ cooking $(\mathrm{VCloss}=35 \%)$, and autoclaving $(\mathrm{VCloss}=37 \%)$ losses reported in published studies [16, 37-39].

Based on the alkaloid sum estimated for the FBPI $(1.36 \mu \mathrm{mole} / \mathrm{g}$, with molar distribution $=74 / 20 / 2 / 4 \mathrm{VC} /$ convicine/divicine/isouramil), a maximum alkaloid sum of $76 \mu$ moles per $\mathrm{kg}$ of NP may be calculated. This estimated alkaloid concentration is $\sim 300 \times$ lower than the corresponding alkaloid estimate (20,000-30,000 $\mu$ moles per $\mathrm{kg})$ calculated for raw fava beans ([29, 30], Khalil et al., [28], Cardador-Martinez et al. 2014, [18]), a difference that is relevant since most cases (">96\%") of favism are associated with the consumption of raw beans (suggesting that the incidence of favism is significantly decreased even by the $20-40 \%$ alkaloid loss and/or by the fava bean $\beta$-glucosidase inactivation induced by cooking) and the fact that the consumption of "a large meal of lowvicine fava beans [the VC was 10-20x lower than that in typical fava beans]" resulted in no favism [40, 41]. A formal evaluation of these safety issues has been documented in a FBPI GRAS application [31].

3.5. $L D$ in FBPIs and NPs. The commercial FBPI was found to contain LD at $13.3 \pm 0.2(n=3) \mathrm{mg}$ per $\mathrm{kg}$ or $1.5 \mathrm{mg}$ of $\mathrm{LD}$ per $100 \mathrm{~g}$ of protein (Figure 2). Comparing this to a LD maximum concentration of $0.6 \mathrm{~g}$ per $\mathrm{kg}$ of dried fava beans [ 6 , 42], and assuming a protein content of $300 \mathrm{~g}$ per $\mathrm{kg}$ of dried beans, the fava bean LD concentration may be estimated at $200 \mathrm{mg}$ per $100 \mathrm{~g}$ protein. It is worth noting that much higher LD concentrations ( $>10 \times$ higher) have been reported for undried fava bean seeds [42-46]. The FBPI protein-based LD concentration would therefore be $\sim 99 \%$ reduced vs. the fava bean protein-based LD concentration, a reduction comparable to the corresponding reduction of VC.

The LD concentrations in the NPs were $<0.05 \mathrm{mg} / \mathrm{kg}$ (vanilla) and $0.17 \mathrm{mg} / \mathrm{kg}$ (chocolate), which correspond to $<0.1 \mathrm{mg} / 100 \mathrm{~g}$ protein (vanilla) and $0.3 \mathrm{mg} / 100 \mathrm{~g}$ protein (chocolate). The NP protein-based LD concentrations are therefore in the range of $1000 \times$ lower than the published fava bean proteinbased LD average concentration ( $200 \mathrm{mg} / 100 \mathrm{~g}$ protein).

As indicated above, the substantial depletion of LD in the FBPI and in the NPs formulated with it is not unexpected, in view of LD's (a) relatively small size (197.2 Da), (b) aqueous solubility (octanol/water partition coefficient $X$ $\log P 3=-2.7)$, and (c) instability to neutral/alkaline $\mathrm{pH}$ and heat ([7,9]; PubChem 2020). These attributes render LD vulnerable to large losses during FBPI and NP processing steps (e.g., washing/centrifugation and sterilization).

3.6. TY in FBPIs and NPs. The commercial FBPI did not contain a quantifiable level of TY, meaning that the TY 


\section{Current Chromatogram (s)}

DAD1 B, Sig = 276,4 Ref = 590,100 (DEF_LC 2019-02-09 09-27-48\001-0102.D)

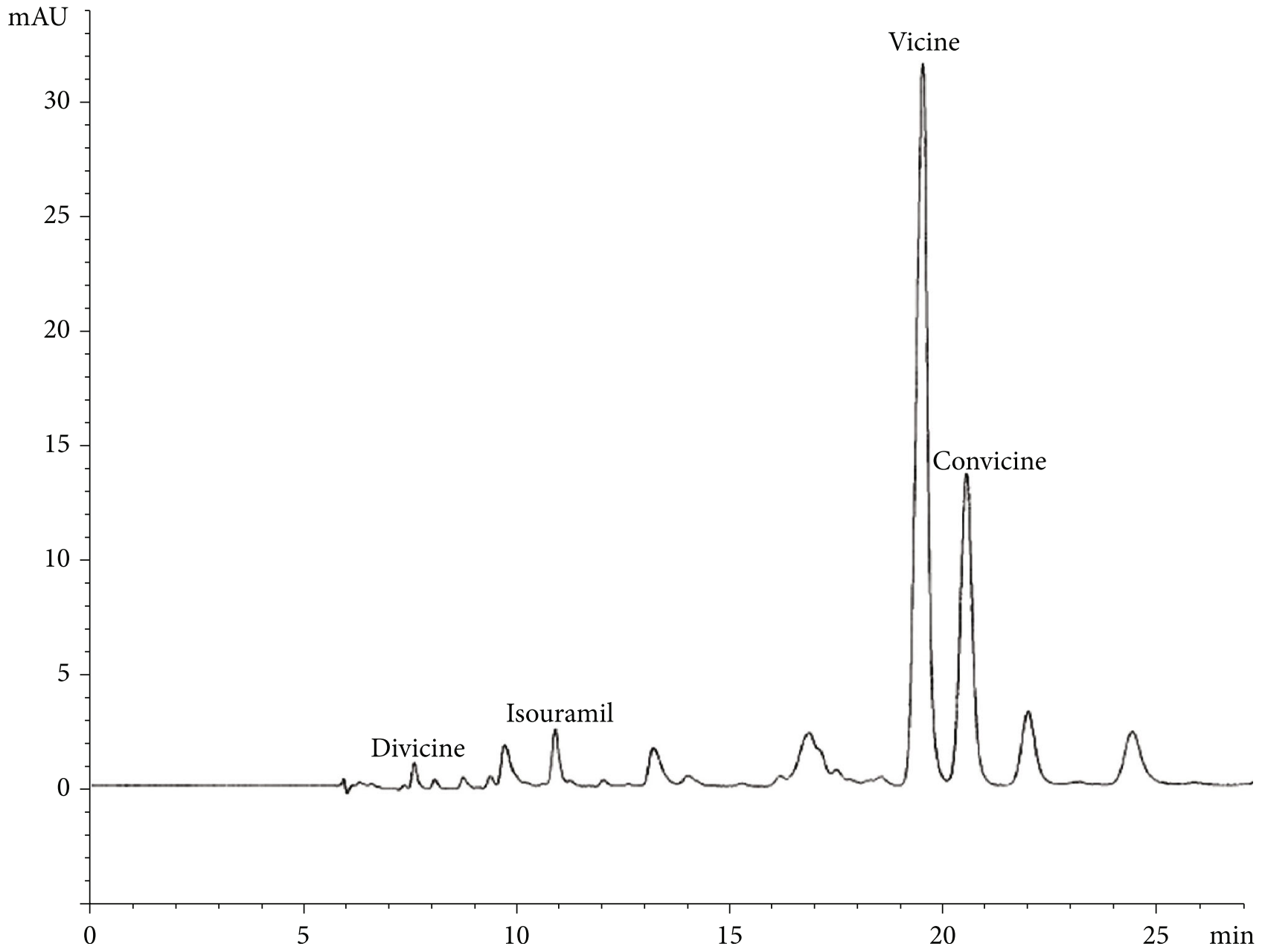

FIGURE 1: LC/UV chromatogram of a commercial fava bean protein isolate, showing the pyrimidine aglycones divicine and isouramil, and the pyrimidine glycosides vicine and convicine.

concentration was $<0.5 \mathrm{mg}$ per $\mathrm{kg}$ or $<0.06 \mathrm{mg}$ of TY per $100 \mathrm{~g}$ of protein. Moret et al. [13] measured TY at $10 \mathrm{mg}$ per $\mathrm{kg}$ or $\sim 4 \mathrm{mg}$ per $100 \mathrm{~g}$ of protein. When expressed on a protein basis, the FBPI protein-based TY concentration is in the range of 9899\% lower than the published fava bean TY concentration [13].

The TY concentration in both NPs was $0.08 \mathrm{mg} / \mathrm{kg}$, which corresponds to $0.14 \mathrm{mg} / 100 \mathrm{~g}$ protein. The NP protein-based TY concentration was therefore $<4 \%$ of the published fava bean protein-based TY concentration ( $\sim 4 \mathrm{mg} / 100 \mathrm{~g}$ protein). It is worth noting that TY was found at $\sim 0.5 \mathrm{mg} / 100 \mathrm{~g}$ protein in the NP's pea protein ingredient (Figure 3 ), which provides $17 \%$ of the total protein in the NP formulation, thereby accounting for the majority $(>60 \%)$ of the TY in the NPs $(0.08 \mathrm{mg} / \mathrm{kg})$.

Finally, as indicated above, the substantial TY depletion in the FBPI (vs. the published fava bean TY concentration) is presumably a consequence of the small size $(137 \mathrm{Da})$ and the water solubility $\left(10.4 \mathrm{~g} / \mathrm{L}\right.$ at $15^{\circ} \mathrm{C}$ [47]) of the TY molecule, facilitating its elimination during FBPI production.

\section{Conclusions}

A commercial FBPI was found to contain VC at $306 \mathrm{mg} / \mathrm{kg}$, $\mathrm{LD}$ at $13.3 \mathrm{mg} / \mathrm{kg}$, and TY at $<0.5 \mathrm{mg} / \mathrm{kg}$. When expressed on a protein basis, these concentrations (34, 1.5, and $<0.06 \mathrm{mg}$ per $100 \mathrm{~g}$ protein, respectively) are at least $96 \%$ lower, $99 \%$ lower, and at least $98 \%$ lower than the VC, LD, and TY concentrations reported for fava beans (when also expressed on a protein basis: $\geq 900 \mathrm{mg}, \sim 200 \mathrm{mg}$, and $\sim 4 \mathrm{mg}$ per $100 \mathrm{~g}$ protein, respectively). The NP formulated with the fava bean protein isolate contained $\mathrm{VC}$ at $13 \mathrm{mg} / \mathrm{kg}$, $\mathrm{LD}$ at $\leq 0.17 \mathrm{mg} / \mathrm{kg}$, and TY at $0.08 \mathrm{mg} / \mathrm{kg}$. When expressed on a protein basis, these concentrations $(22, \leq 0.3$, and $0.14 \mathrm{mg}$ per $100 \mathrm{~g}$ protein, respectively) are $97 \%$ lower, $>99 \%$ lower, and $96 \%$ lower than the fava bean (proteinbased) VC, LD, and TY concentrations. The corresponding concentrations delivered by one serving ( $11 \mathrm{fl}$. oz.) of the $\mathrm{NP}$ would therefore be approximately $5 \mathrm{mg}$ of $\mathrm{VC},<1 \mathrm{mg}$ of $\mathrm{LD}$, and $<0.1 \mathrm{mg}$ of TY. 


\section{Current Chromatogram (s)}

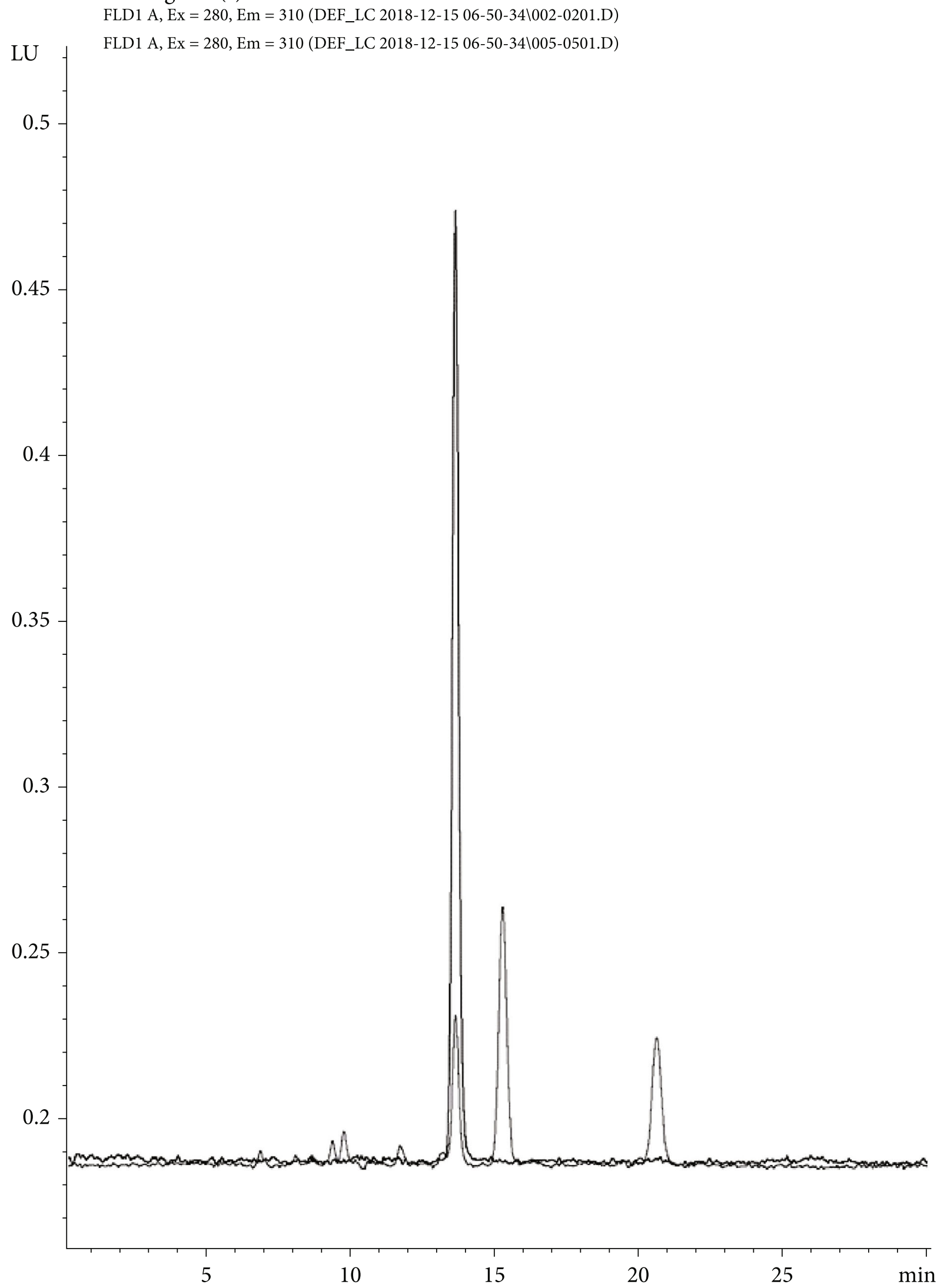

FIGURE 2: Superimposed LC/UV chromatograms of a levodopa standard solution (with the taller levodopa peak at 13-14 minutes) and a commercial fava bean protein isolate (with the shorter levodopa peak at 13-14 minutes). 
Current Chromatogram (s)

FLD1 A, Ex = 275, Em = 303 (DEF_LC 2018-12-03 13-54-50\008-0801.D)

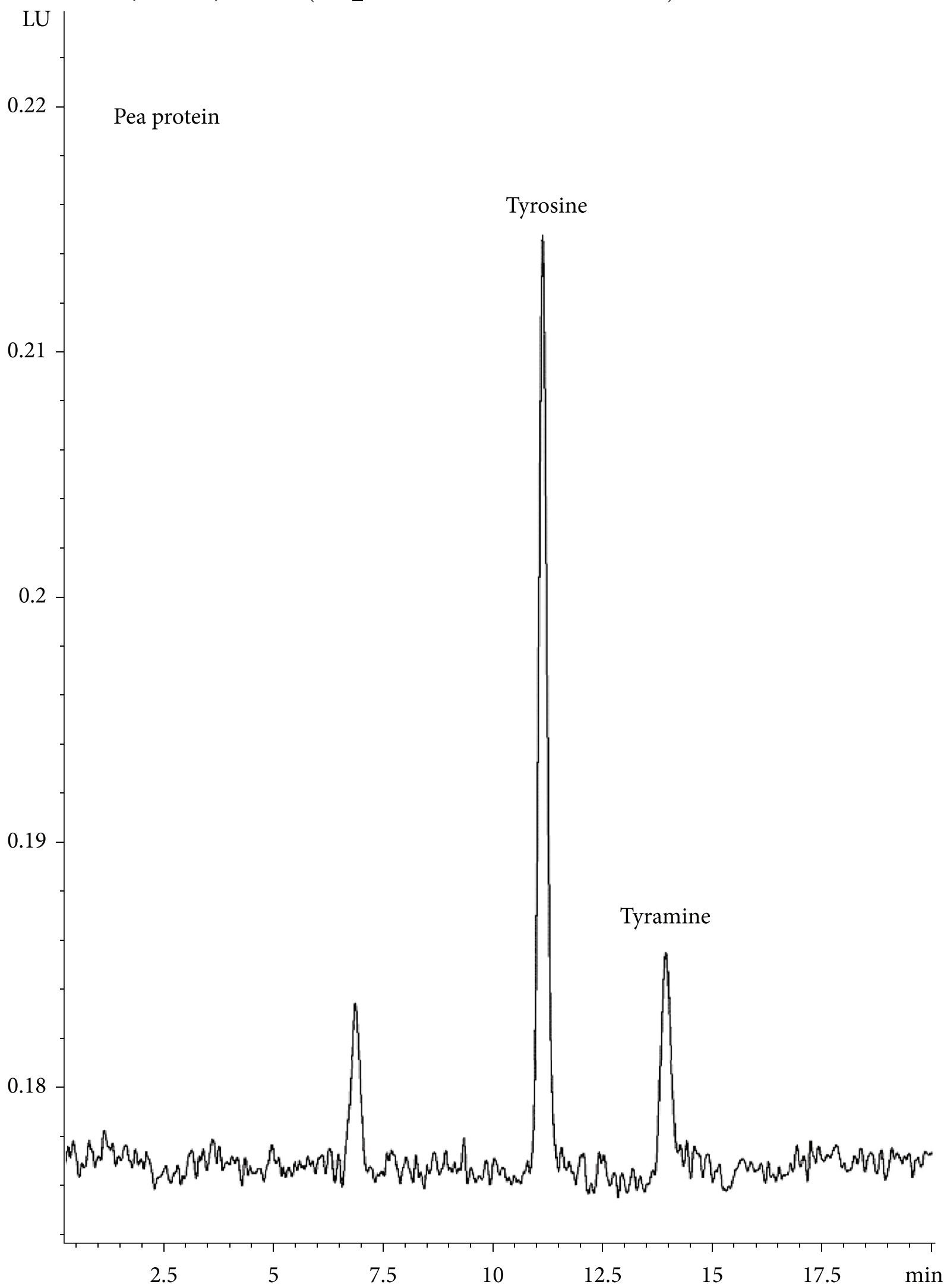

FIGURE 3: LC/FLD chromatogram of the pea protein ingredient, showing tyrosine and tyramine. 


\section{Data Availability}

All supporting data are included in the manuscript.

\section{Consent}

No consent is necessary.

\section{Conflicts of Interest}

It should be noted that all testing of the Abbott nutritional products was performed by an Abbott analyst (Paul W. Johns). Paul W. Johns declares that he has no other conflict of interest or competing interest. Steven R. Hertzler declares that he has no conflict of interest or competing interest.

\section{Authors' Contributions}

Steven R. Hertzler is responsible for the conceptualization, data curation, writing of the first draft, writing of the review, and editing. Paul W. Johns is responsible for the conceptualization, formal analysis, validation, data curation, writing of the first draft, writing of the review, and editing.

\section{Supplementary Materials}

Graphical abstract. The vicine, levodopa, and tyramine concentrations (relative to the fava bean concentrations) in a commercial fava bean protein isolate and in a nutritional product formulated with the commercial isolate. All concentrations are expressed as \% of the fava bean concentration, and all concentrations are expressed on a protein basis (mass per unit protein). (Supplementary Materials)

\section{References}

[1] S. Multari, M. Neacsu, L. Scobbie et al., "Nutritional and phytochemical content of high-protein crops," Journal of Agricultural and Food Chemistry, vol. 64, no. 41, pp. 7800-7811, 2016.

[2] I. Leinonen, P. P. M. Iannetta, R. M. Rees, W. Russell, C. Watson, and A. P. Barnes, "Lysine supply is a critical factor in achieving sustainable global protein economy," Frontiers in Sustainable Food Systems, vol. 3, p. 27, 2019.

[3] A. Karkanis, G. Ntatsi, L. Lepse et al., "Faba bean cultivation revealing novel managing practices for more sustainable and competitive European cropping systems," Frontiers in Plant Science, vol. 9, p. 1115, 2018.

[4] A. Kimura, T. Fukuda, M. Zhang, S. Motoyama, N. Maruyama, and S. Utsumi, "Comparison of physicochemical properties of $7 \mathrm{~S}$ and 11S globulins from pea, fava bean, cowpea, and French bean with those of soybean - French bean $7 \mathrm{~S}$ globulin exhibits excellent properties," Journal of Agricultural and Food Chemistry, vol. 56, no. 21, pp. 10273-10279, 2008.

[5] C. G. Rizzello, I. Losito, L. Facchini et al., "Degradation of vicine, convicine and their aglycones during fermentation of faba bean flour," Scientific Reports, vol. 6, p. 32542, 2016.

[6] S. Multari, D. Stewart, and W. R. Russell, "Potential of fava bean as future protein supply to partially replace meat intake in the human diet," Comprehensive Reviews in Food Science and Food Safety, vol. 14, no. 5, pp. 511-522, 2015.
[7] X. Chen, J. Zhang, H. Zhai, X. Chen, and Z. Hu, "Determination of levodopa by capillary zone electrophoresis using an acidic phosphate buffer and its application in the analysis of beans," Food Chemistry, vol. 92, no. 2, pp. 381-386, 2005.

[8] O. Hornykiewicz, "L-DOPA: from a biologically inactive amino acid to a successful therapeutic agent," Amino Acids, vol. 23, no. 1-3, pp. 65-70, 2002.

[9] P. Siddhuraju and K. Becker, "Rapid reversed-phase high performance liquid chromatographic method for the quantification of L-Dopa (L-3,4-dihydroxyphenylalanine), non-methylated and methylated tetrahydroisoquinoline compounds from Mucuna beans," Food Chemistry, vol. 72, no. 3, pp. 389-394, 2001.

[10] A. C. Whitfield, B. T. Moore, and R. N. Daniels, "Classics in chemical neuroscience: levodopa," ACS Chemical Neuroscience, vol. 5, no. 12, pp. 1192-1197, 2014.

[11] N. Benkerroum, "Biogenic amines in dairy products: origin, incidence, and control means," Comprehensive Reviews in Food Science and Food Safety, vol. 15, no. 4, pp. 801-826, 2016.

[12] B. J. McCabe-Sellers, C. G. Staggs, and M. L. Bogle, “Tyramine in foods and monoamine oxidase inhibitor drugs: a crossroad where medicine, nutrition, pharmacy, and food industry converge," Journal of Food Composition and Analysis, vol. 19, pp. S58-S65, 2006.

[13] S. Moret, D. Smela, T. Populin, and L. S. Conte, "A survey on free biogenic amine content of fresh and preserved vegetables," Food Chemistry, vol. 89, no. 3, pp. 355-361, 2005.

[14] A. R. Shalaby, "Significance of biogenic amines to food safety and human health," Food Research International, vol. 27, pp. 675-690, 1996.

[15] S. A. N. Tailor, K. Shulman, S. E. Walker, J. Moss, and D. Gardner, "Hypertensive episode associated with phenelzine and tap beer-a reanalysis of the role of pressor amines in beer," Journal of Clinical Psychopharmacology, vol. 14, no. 1, pp. 514, 1994.

[16] A. H. Khalil and E. H. Mansour, "The effect of cooking, autoclaving and germination on the nutritional quality of faba beans," Food Chemistry, vol. 54, no. 2, pp. 177-182, 1995.

[17] J. Vioque, M. Alaiz, and J. Giron-Calle, "Nutritional and functional properties of Vicia faba protein isolates and related fractions," Food Chemistry, vol. 132, no. 1, pp. 67-72, 2012.

[18] M. Pulkkinen, M. Gautam, A. M. Lampi et al., "Determination of vicine and convicine from faba bean with an optimized high- performance liquid chromatographic method," Food Research International, vol. 76, pp. 168-177, 2015.

[19] M. Pulkkinen, X. Zhou, A. M. Lampi, and V. Piironen, "Determination and stability of divicine and isouramil produced by enzymatic hydrolysis of vicine and convicine of faba bean," Food Chemistry, vol. 212, pp. 10-19, 2016.

[20] M. Pulkkinen, R. Coda, A. M. Lampi, J. Varis, K. Katina, and V. Piironen, "Possibilities of reducing amounts of vicine and convicine in faba bean suspensions and sourdoughs," European Food Research and Technology, vol. 245, no. 7, pp. 1507-1518, 2019.

[21] M. Vogelsang-O'Dwyer, I. L. Petersen, M. S. Joehnke et al., "Comparison of faba bean protein ingredients produced using dry fractionation and isoelectric precipitation: techno-functional, nutritional and environmental performance," Food, vol. 9, no. 3, p. 322, 2020.

[22] J. H. Baxter, R. R. Phillips, L. Dowlati, K. C. Goehring, and P. W. Johns, "Direct determination of $\beta$-hydroxy- $\beta$ - 
methylbutyrate (HMB) in liquid nutritional products," Food Analytical Methods, vol. 4, no. 3, pp. 341-346, 2011.

[23] J. H. Baxter and P. W. Johns, "Determination of free arginine, glutamine, and $\beta$-alanine in nutritional products and dietary supplements," Food Analytical Methods, vol. 5, no. 4, pp. 821-827, 2012.

[24] P. Johns, R. Phillips, and L. Dowlat, "Direct determination of free methionine in soy-based infant formula," Journal of AOAC International, vol. 87, no. 1, pp. 123-128, 2004.

[25] P. W. Johns, J. H. Baxter, and M. C. Terp, "Verification of 5methyltetrahydrofolic acid in nutritional products," Food Analytical Methods, vol. 10, no. 10, pp. 3255-3263, 2017.

[26] J. Vial and A. Jardy, "Experimental comparison of the different approaches to estimate LOD and LOQ of an HPLC method," Analytical Chemistry, vol. 71, no. 14, pp. 2672-2677, 1999.

[27] P. R. Cheeke, Toxicants of Plant Origin, Volume II. Glycosides. CRC Press, Boca Raton, FL, USA, 1989.

[28] C. Goyoaga, C. Burbano, C. Cuadrado et al., "Content and distribution of vicine, convicine and L-DOPA during germination and seedling growth of two Vicia faba L. varieties," European Food Research and Technology, vol. 227, no. 5, pp. 1537-1542, 2008.

[29] M. I. Hegazy and R. R. Marquardt, "Development of a simple procedure for the complete extraction of vicine and convicine from faba beans (Vicia faba? L.)," Journal of the Science of Food and Agriculture, vol. 34, no. 1, pp. 100-108, 1983.

[30] W. J. Pitz, F. W. Sosulski, and G. G. Rowland, "Effect of genotype and environment on vicine and convicine levels in faba beans (Vicia faba minor)," Journal of the Science of Food and Agriculture, vol. 32, no. 1, pp. 1-8, 1981.

[31] D. F. Schmitt, "GRAS determination of fava bean protein for use as an ingredient in human food," 2019, GRAS Notice (GRN) No. 879.

[32] C. Wang, Q. Ma, S. Pagadala, M. S. Sherrard, and P. G. Krishnan, "Changes of isoflavones during processing of soy protein isolates," Journal of the American Oil Chemists' Society, vol. 75, no. 3, pp. 337-341, 1998.

[33] I. V. Tetko, J. Gasteiger, R. Todeschini et al., "Virtual computational chemistry laboratory - design and description," Journal of Computer-Aided Molecular Design, vol. 19, no. 6, pp. 453-463, 2005.

[34] VCCLAB, Virtual Computational Chemistry Laboratory, 2005, http://www.vcclab.org.

[35] P. W. Johns, S. M. Fawcett, R. R. Phillips, and G. C. Patel, "Variation of indoxyl and cresol sulphates in milk protein commodities," International Dairy Journal, vol. 20, no. 2, pp. 113-120, 2010.

[36] H. Zhang, Y. Tao, Y. He et al., "Preparation of low-lactose milk powder by coupling membrane technology," ACS Omega, vol. 5, no. 15, pp. 8543-8550, 2020.

[37] M. A. Abd Allah, Y. H. Foda, F. M. Abu Salem, and Z. S. Abd Allah, "Treatments for reducing total vicine in Egyptian faba bean (Giza 2 variety)," Plant Foods for Human Nutrition, vol. 38, no. 3, pp. 201-210, 1988.

[38] A. Cardador-Martinez, K. Maya-Ocana, A. Ortiz-Moreno et al., "Effect of roasting and boiling on the content of vicine, convicine and L-3,4-dihydroxyphenylalanine in Vicia faba L," Journal of Food Quality, vol. 35, no. 6, p. 428, 2012.

[39] C. A. Patterson, J. Curran, and T. Der, "Effect of processing on antinutrient compounds in pulses," Cereal Chemistry, vol. 94, no. 1, pp. 2-10, 2017.
[40] P. Arese, G. Duc, M. Lessire, and P. Marget, "Low vicineconvicine and zero tannin "FEVITA" faba beans," Grain Legumes, vol. 48, pp. 16-17, 2007.

[41] L. Luzzatto and P. Arese, "Favism and glucose-6-phosphate dehydrogenase deficiency," New England Journal of Medicine, vol. 378 , no. 1, pp. 60-71, 2018.

[42] C. Burbano, C. Cuadrado, M. Muzquiz, and J. I. Cubero, "Variation of favism-inducing factors (vicine, convicine and L-DOPA) during pod development in Vicia faba L," Plant Foods for Human Nutrition, vol. 47, no. 3, pp. 265274, 1995.

[43] C. A. Oviedo-Silva, M. Elso-Freudenberg, and M. ArandaBustos, "L-DOPA trends in different tissues at early stages of Vicia faba growth: effect of tyrosine treatment," Applied Sciences, vol. 8, no. 12, p. 2431, 2018.

[44] R. Randhir, P. Shetty, and K. Shetty, "L-DOPA and total phenolic stimulation in dark germinated fava bean in response to peptide and phytochemical elicitors," Process Biochemistry, vol. 37, no. 11, pp. 1247-1256, 2002.

[45] P. Shetty, M. T. Atallah, and K. Shetty, "Effects of UV treatment on the proline-linked pentose phosphate pathway for phenolics and L-DOPA synthesis in dark germinated Vicia faba," Process Biochemistry, vol. 37, no. 11, pp. 1285-1295, 2002.

[46] D. A. VATTEM, R. RANDHIR, and K. SHETTY, "Cranberry phenolics-mediated elicitation of antioxidant enzyme response in fava bean (Vicia faba) sprouts," Journal of Food Biochemistry, vol. 29, no. 1, pp. 41-70, 2005.

[47] S. H. Yalkowski and R. M. Dannenfelser, The Aquasol Database of Aqueous Solubility, University of Arizona College of Pharmacy, Tucson, Arizona, USA, 5th edition edition, 1992.

[48] D. C. McMillan, K. L. Schey, G. P. Meier, and D. J. Jollow, "Chemical analysis and hemolytic activity of the fava bean aglycon divicine," Chemical Research in Toxicology, vol. 6, no. 4, pp. 439-444, 1993.

[49] "PubChem CID 6047," 2020, Levodopa. http://pubchem.ncbi .nlm.nih.gov. 